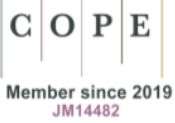

Anna Walczak*

Marek Budajczak**

Artur Jocz $^{* * *}$

\title{
On the (un)Ending Need for Spirituality in Human Life and Education. Introductory Remarks
}

\begin{abstract}
In the context of considerations about the presence and absence of the Spirit and spirituality in the world, understanding this category and relating it to the educational sciences in an interdisciplinary approach, a description of the content of the $12^{\text {th }}$ volume of the journal "Educational Sciences. Interdisciplinary Studies".
\end{abstract}

Keywords: spirit, spirituality, transcendence, condition of human existence, multi/ interdisciplinarity.

\section{0 (nie)ustającej potrzebie duchowości w życiu i wychowaniu człowieka. Uwagi wstępne}

\begin{abstract}
Abstrakt
W kontekście rozważań o obecności i nieobecności Ducha oraz duchowości w świecie, pojmowania tej kategorii i odniesienia jej do nauk o wychowaniu w ujęciu interdyscyplinarnym omówiono zawartość 12 tomu czasopisma „Nauki o Wychowaniu. Studia Interdyscyplinarne".
\end{abstract}

Słowa kluczowe: duch, duchowość, transcendencja, kondycja ludzkiej egzystencji, multi/interdyscyplinarność.

\footnotetext{
* University of Lodz.

** University of Adam Mickiewicz in Poznan.

*** University of Adam Mickiewicz in Poznan.

Article received: 29.03.2021; accepted: 30.03.2021.
} 
In building his intellectually bold and highly allegorical interpretation of the phenomenon of the creative act of God, Origen (c. 186-c. 253) referring to the Book of Genesis wrote:

First, He created heaven, of which He says: "Heaven is my throne" (Is 66: 1). Then He creates the vault, that is, the material heaven (...). Everything that God was to create had to consist of spirit and flesh; therefore it was said that "in the beginning" and above all, heaven was created, that is, every spiritual substance upon which God rests, as if on some stool or throne. But this sky, or vault, is something carnal. Therefore, this first heaven, which we have called the spiritual heaven, is our mind, which is also spirit itself, so it is our spiritual man who sees and watches God (Origen 1995: 58).

From the quoted words of the Alexandrian, it can be clearly read that the spiritual substance appears to him as the foundation of the process of world creation. The spiritual dimension of existence is evidently more important than the material dimension of existence. This is the case, inter alia, because in His deepest essence God is a Spiritual Being and does not manifest in material form. Therefore, in material reality only through the Spirit is it possible for God and man to meet. Thus, only the spiritual element is common to God and man. Sensuality, on the other hand, is what separates them. The attentive reader should, of course, note that in the quoted reflections of Origen, not a single word is uttered about the soul. The reason for this peculiar omission is its genesis. The Alexandrian explains this, beginning as follows:

So if what is holy is called fire, flame and heat, and all the opposite of holiness is defined as something cold, and it has been said that the love of sinners will "chill", one has to wonder if the name "soul", the psyche in Greek, does not come from the "cooling" of the better, divine state, because the soul has grown cold in the natural divine heat, and for this very reason it has such a nature and name (Origen 1996: 191).

Building the foundations for these considerations, Origen referred to philological inquiries and derived the word soul (psyche) from the word to cool (psychestai) (cf. footnote no. 30 Origen 1996: 191). It was for this reason that he proclaimed that the soul arose as a result of the cooling of a spiritual being that had distanced itself from God. In this way, at the very beginning of the formation of the foundations of the Christian tradition, and in a natural way of European culture, he made a fundamental appreciation of the spiritual reality, which he considered transcendent to the secondary material world. Origen thus built an intellectual bridge between nascent Christian thought and the achievements of Greek 
metaphysics, which, thanks to Plato's reflections (427-347), similarly hyperbolized the meaning of the world of ideas.

The primacy of the spiritual reality was not threatened by the duality of soul and body, which, with his authority, was finally consolidated in Christianity by St. Augustine (354-430). He devoted much intellectual attention to proving the immortality of the soul and the existence of God, and thus discreetly overshadowed the threefold (spirit, soul, body) vision of human nature promoted by Origen. However, he tried to perpetuate and awaken in this nature the desire to seek God - the Spirit, transcendent to material beings. This was primarily the mystical search for the Absolute, which was possible only in the spiritual dimension.

Of course, after centuries, somewhat maliciously, but at the same time very precisely, this type of intellectual activity was assessed by Hegel (1770-1831), who in his early writings on the philosophy of religion stated: "The main teachings of the Christian religion have remained identical since its inception, but depending on the circumstances, some of them were removed into the shadows, while others were carried out, placed in the light (...)" (Hegel 1999: 8). The quoted statement, however, does not only concern the specific, historically embedded religion - Christianity. The words of the German philosopher contain an intellectually bold statement about the dynamic nature of changes in the area of classical metaphysics and their enormous influence on the shape of European culture. This is what happened after the fam-ous statement by Friedrich Nietzsche (1844-1900), who announced the death of God. Did he thus foretell the final end of the Spirit, spirituality, and man's transcendent aspirations? It was Nikolai Berdyaev (18741948) who was afraid of this type of consequence, and in his The End of our Time, he wrote about a peculiar twilight of the "spiritual man" and the final, inevitable subordination of humanity to the machine. The measurable effect of this process was to be the birth of the dictatorship of universal industrialization, ruthless in its materialistic determinism, which inevitably led to the annihilation of vital freedom, i.e. a substantial feature of animate nature (Berdyaev 2003: 28-35). A more dramatic diagnosis of the ultimate end of the spiritual dimension of human existence can be read only in the pages of Negative Dialectics by Theodor W. Adorno (1903-1969). He unequivocally states that the so-called spirit of European civilization could in no way stop the machine of the Holocaust being dispersed by the Germans. He revealed this frightening phenomenon in the following words:

The fact that this could have happened in the midst of an entire tradition of philosophy, art, and enlightening sciences says more than that this tradition, that spirit, was unable to overwhelm people and change them. In those spheres themselves, in their emphatic claim to autarky, lies the untruth. All culture after Auschwitz, including its most penetrating critique, is a garbage can (Adorno 1986: 514-515). 
So, is there any hope left for the Spirit, spirituality, and transcendence after the totalitarian regimes of the twentieth century? Such hope seems to be contained in The Concept of God after Auschwitz by Hans Jonas (1903-1993). Presenting his reflections, Jonas tries to free God from responsibility for the Holocaust and thus remove from Him the moral shame of refraining from intervening in a world corrupted by institutional murderers. However, there is an immanent problem in what he proposed, because, with incredible spiritual courage, he declared that God is not omnipotent (Jonas 2003: 40-46).

In order to save the Spirit, spirituality, and transcendence, it is necessary to be intellectually and spiritually courageous. The authors of this thematic volume of "Educational Sciences. Interdisciplinary Studies", which we, the scientific editors (Anna Walczak, Marek Budajczak, Artur Jocz) have entitled (Non)presence of Spirituality and the Educational Sciences are undoubtedly so.

The articles presented to the reader are published in the following sections of the journal: Studies and Dissertations, Research Reports and Discussions/ Polemics/Reviews. However, all these extremely interesting considerations are held together by the jaws of a kind of clamp. On the one hand, an article by Janusz Mariański (On New Spirituality - an Attempt to Describe the Phenomenon), and on the other hand, a text by Agnieszka Wiatrowska and Andrzej Pankalla (The Case of the Anti-spirituality of the Orthodox Behaviorist B. F. Skinner - A Psychobiographic Perspective).

In both texts, some kind of ontological foundations of spirituality are discussed. Mariański's multidimensional (sociological and religious studies) considerations introduce the reader to the complex issues of contemporary spiritual seeking and human desires. Their basic feature is a far-reaching individualism of spiritual needs and a programmatic distance from official religious institutions. An additional advantage of the article is the extensive bibliography, which will be an excellent guide for any reader who would like to conduct further independent studies on the subject matter. In turn, Agnieszka Wiatrowska and Andrzej Pankalla construct their article in an unintended but inspiring opposition to Mariański's thoughts. They show the process of freeing man from the need for the spiritual foundation of the personality and replacing it with a scientific method that by definition denies the real existence of spiritual reality. It is, of course, the behaviorism of B. F. Skinner (1904-1990). The strength of this article is that the authors indicate the role that the religious upbringing received by Skinner played in this process. Among the texts collected in the discussed volume, the most important are considerations devoted to the need to really take into account the spiritual dimension of reality in the broadly understood process of education. Their authors try to show the ontological foundations of the identified relation and some specific examples. The aforementioned foundations are sought, for example, by Anna Walczak ("Strong" and "Weak" Interpretations of Spirituality and the Educational Sciences), who uses the achievements of philosophical hermeneutics 
and strives to clarify the ways of interpreting the category of spirituality. This kind of hermeneutic study of spirituality still seems necessary. In turn, Sławomir Sztobryn (The Concept of Spirituality in the Tradition of Polish Secular Pedagogical Thought), Krystyna Ablewicz (Awareness of Spirit Corporeality and Body Spirituality within the Process of Educating Humans. A Description within the Context of Alexander Lowen's Bioenergetics Analysis of Character and Max Scheler's Order of Values), Maja Dobiasz-Krysiak (A Spirit that Suffers. The Role of Suffering and Ritual in Experiencing Crises through the Example of the Waldorf School), and Justyna Sztobryn-Bochomulska (The Reflective-Existential Dimension of Thanatopedagogy an Area Supporting Human Development) try to present the manifestation of the phenomenon of the Spirit and the category of spirituality in various pedagogical conceptions and educational systems. On the other hand, Marek Budajczak (Spiritualizing Education and Education that is Spiritualized), Witold Glinkowski (Spiritual Life and Living in the Spirit - Martin Buber's Dialogical Distinction), Małgorzata Krakowiak ( $A$ Lesson in Dignity, a Lesson in the Human Spirit by Józef Czapski), Iwona Grodź ("The Truth of the Heart". The Audiovisual Essay by Piotr Załuski: Herbert. Fresco in the Church (2005-2006) used in a Polish Language Lesson), Aleksandra Kilian and Andrzej Pankalla (Deegoization as the Aim of Education - the Soul Paradigm), Brian D. Ray (All Education is Spiritual and ergo Homeschooling is Resurging), Andrew Pudewa (However Imperfectly: Lessons Learned from Thirty Years of Teaching) approach the issue of the presence of the category of spiritual reality in the process of human education in a pragmatic way. This pragmatism consists primarily in showing the Reader the methods of familiarizing the participants of the educational process with the phenomenon of the Spirit and the categories of spirituality and transcendence. Therefore, Marek Budajczak discusses various ways of teaching religion at school and assumes that they are not only a manifestation of the religious beliefs of the majority of society, but also a way that enables the student to actually come closer to the sphere of the sacred. However, in the second part of his article, he shows that this sphere of the sacred is necessary to maintain and strengthen the vitality of European culture. Małgorzata Krakowiak also refers to the sacred sphere (which is a manifestation of the Spirit and spiritual reality) and the mystery related to it. Discussing the phenomenon of the works of Józef Czapski (1896-1993), the author subtly invites the reader to learn about the literary and artistic ways of visualizing the mystery mentioned above, which is an immanent feature of sacred reality. Another road to the sphere of the sacred is mentioned by Witold Glinkowski, who in his article introduces the phenomenon of the philosophy of dialogue by Martin Buber (1878-1965). It is an opportunity to establish a direct personal dialogue with God, that is, a Being existing only in the spiritual dimension. Transferring Glinkowski's thoughts to the most basic level of the educational process, it should be said that it is in school, in the classroom, that a real dialogue between the teacher and the student is absolutely necessary. This type of dialogue can sometimes happen, for 
example, during a Polish language lesson when discussing the film visualization of the spiritual aspects of Zbigniew Herbert's (1924-1998) work. Iwona Grodź writes about this unusual lesson experience for students and teachers. At this point, however, it is worth recalling that to carry out this truly dialogical lesson, it is necessary to distance ourselves from the selfishness that is natural for man. The article by Aleksandra Kilian and Andrzej Pankalla is devoted to the process of deegoisation. Or maybe it is easier and more effective to learn this truly dialogical and soulful lesson during home education? Brian D. Ray and Andrew Pudewa discuss this type of teaching and education in a comprehensive manner. It is worth reading carefully, because this type of education is still a taboo subject in Poland.

We hope that the content of the articles presented in the 12th issue of "Nauki o Wychowaniu. Interdisciplinary Studies" reflects the multi-faceted nature of the problem of spirituality from the multi/interdisciplinary perspective - spirituality, which we considered relevant for the condition of human existence in the modern world, as well as in the educational sciences, the sources of which can be found in Wilhelm Dilthey's Geisteswissenschaften (1833-1911).

Therefore, we encourage you to enjoy an insightful and inspiring read.

\section{References}

Adorno T. W. (1986) Dialektyka Negatywna, transl. K. Krzemieniowa, Warszawa, PWN.

Berdyaev N. (2003) Nowe Średniowiecze. Los człowieka we współczesnym świecie, transl. H. Paprocki, Warszawa, Fundacja Aletheia.

Hegel G. W. F. (1999) Pisma wczesne z filozofii religii, transl. G. Sowinski. Kraków, Wydawnictwo Znak.

Jonas H. (2003) Idea Boga po Auschwitz, transl. G. Sowinski, Kraków, Wydawnictwo Znak.

Origen (1995) Duch i Ogień, Wybór tekstów H.U. von Balthasar, transl. S. Kalinkowski, Kraków, Wydawnictwo M.

Origen (1996 ) O zasadach (II, VIII, 3), transl. S. Kalinkowski, Kraków, Wydawnictwo WAM. 